Teaching NeuroImages:

A neuroendocrine rarity

Section Editor

Mitchell S.V. Elkind,

MD, MS

\title{
Wolfram syndrome
}

Thiago Cardoso Vale, MD

Francisco Otaviano Lima Perpétuo, MD

Correspondence to

Dr. Vale:

thiagocardosovale@hotmail.com

Figure Wolfram syndrome type 1 in a 32-year-old man with deafness and insulin-dependent diabetes mellitus since infancy and a 4-year progressive visual loss and episodes of hyponatremia due to polyuria and polydipsia

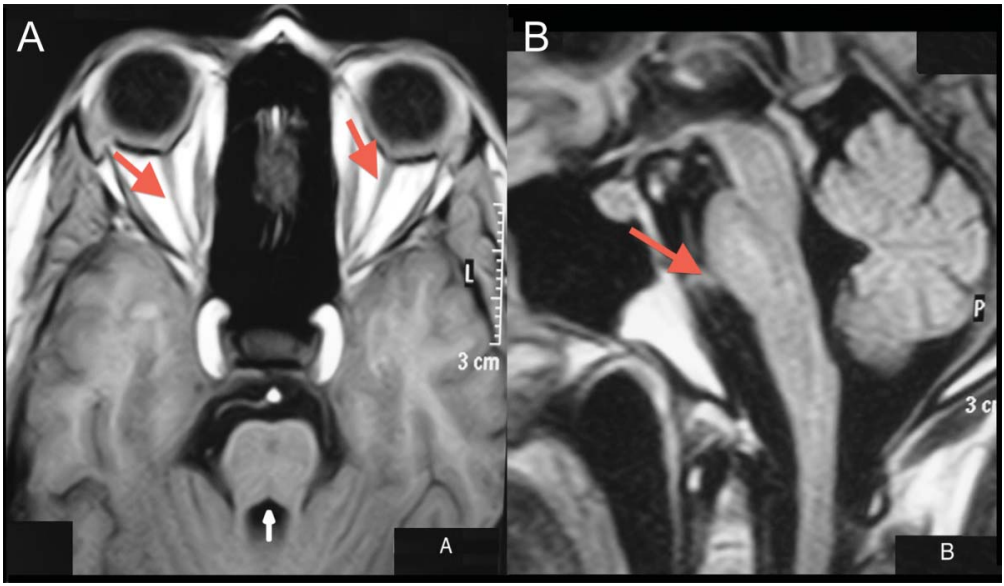

(A) Axial T1-weighted brain MRI shows bilateral optic nerve (red arrows) and pontine and middle cerebellar peduncle atrophy (white arrow). (B) Sagittal T1-weighted brain MRI shows brainstem (particularly the pons; red arrow) and cerebellar atrophy.

Wolfram syndrome 1 (WS1) is an autosomal recessive disorder characterized by diabetes insipidus, diabetes mellitus, optic atrophy, and deafness (DIDMOAD syndrome). It is caused by a mutation in the WFS1 gene (chromosome 4p16.1, involved in regulation of intracellular calcium) that encodes wolframin, a transmembrane protein of pancreatic $\beta$ cells. WS1 is a rare disorder characterized by the development of insulin-dependent diabetes mellitus at an average age of 6 years, followed by optic atrophy (figure) at an average age of 11 and partial central diabetes insipidus and deafness in adolescence. Additional neurologic manifestations include truncal ataxia, myoclonus, epilepsy, nystagmus, and hyposmia. ${ }^{1,2}$

\section{AUTHOR CONTRIBUTIONS}

Thiago Cardoso Vale: drafting/revising the manuscript, study concept or design, analysis or interpretation of data, accepts responsibility for conduct of research and final approval, acquisition of data, study supervision. Francisco Otaviano Lima Perpétuo: drafting/revising the manuscript, study concept or design, analysis or interpretation of data, accepts responsibility for conduct of research and final approval, acquisition of data, study supervision.

\section{STUDY FUNDING}

No targeted funding reported.

\section{DISCLOSURE}

The authors report no disclosures relevant to the manuscript. Go to Neurology.org for full disclosures.

\section{REFERENCES}

1. Rigoli L, Di Bella C. Wolfram syndrome 1 and Wolfram syndrome 2. Curr Opin Pediatr 2012;24:512-517.

2. Ito $S$, Sakakibara R, Hattori T. Wolfram syndrome presenting marked brain MR imaging abnormalities with few neurologic abnormalities. AJNR Am J Neuroradiol 2007;28: 305-306.
Download teaching slides: www.neurology.org
From the Neurology Division (T.C.V.) and the Radiology Division (F.O.L.P.), University Hospital, Faculty of Medicine, Federal University of Minas Gerais (UFMG), Belo Horizonte, Minas Gerais, Brazil. 


\section{Neurology}

\section{Teaching NeuroImages: A neuroendocrine rarity: Wolfram syndrome Thiago Cardoso Vale and Francisco Otaviano Lima Perpétuo \\ Neurology 2013;81;e153 \\ DOI 10.1212/01.wnl.0000435559.06072.d6}

This information is current as of November 11, 2013

\begin{tabular}{|c|c|}
\hline $\begin{array}{l}\text { Updated Information \& } \\
\text { Services }\end{array}$ & $\begin{array}{l}\text { including high resolution figures, can be found at: } \\
\text { http://n.neurology.org/content/81/20/e153.full }\end{array}$ \\
\hline Supplementary Material & $\begin{array}{l}\text { Supplementary material can be found at: } \\
\mathrm{http} / / / \text { n.neurology.org/content/suppl/2013/11/09/81.20.e153.DC1 }\end{array}$ \\
\hline References & $\begin{array}{l}\text { This article cites } 2 \text { articles, } 0 \text { of which you can access for free at: } \\
\text { http://n.neurology.org/content/81/20/e153.full\#ref-list-1 }\end{array}$ \\
\hline Subspecialty Collections & $\begin{array}{l}\text { This article, along with others on similar topics, appears in the } \\
\text { following collection(s): } \\
\text { All Pediatric } \\
\text { http://n.neurology.org/cgi/collection/all_pediatric } \\
\text { Endocrine } \\
\text { http://n.neurology.org/cgi/collection/endocrine } \\
\text { MRI } \\
\text { http://n.neurology.org/cgi/collection/mri } \\
\text { Neuroendocrinology } \\
\text { http://n.neurology.org/cgi/collection/neuroendocrinology } \\
\text { Optic nerve } \\
\text { http://n.neurology.org/cgi/collection/optic_nerve }\end{array}$ \\
\hline Permissions \& Licensing & $\begin{array}{l}\text { Information about reproducing this article in parts (figures,tables) or in } \\
\text { its entirety can be found online at: } \\
\text { http://www.neurology.org/about/about_the_journal\#permissions }\end{array}$ \\
\hline Reprints & $\begin{array}{l}\text { Information about ordering reprints can be found online: } \\
\text { http://n.neurology.org/subscribers/advertise }\end{array}$ \\
\hline
\end{tabular}

Neurology ${ }^{\circledR}$ is the official journal of the American Academy of Neurology. Published continuously since 1951, it is now a weekly with 48 issues per year. Copyright @ 2013 American Academy of Neurology. All rights reserved. Print ISSN: 0028-3878. Online ISSN: 1526-632X.

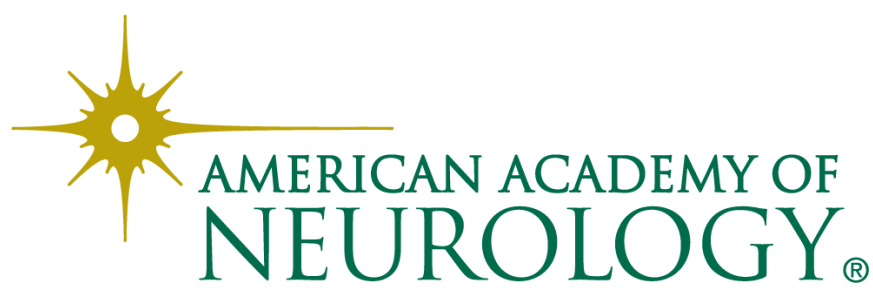

